\title{
Article \\ The Effects of Polyphenol-Rich Black Elderberry on Oxidative Stress and Hepatic Cholesterol Metabolism
}

\author{
Sohyeon Jeon ${ }^{1,+}$, Sanggil Lee ${ }^{2, \dagger}$, Yeoni Choi ${ }^{1}$ and Bohkyung Kim ${ }^{1, *}$ \\ 1 Department of Food Science and Nutrition, Pusan National University, Busan 46241, Korea; \\ hyeoneee@pusan.ac.kr (S.J.); choiyeoni77@pusan.ac.kr (Y.C.) \\ 2 Department of Food Science and Nutrition, Pukyong National University, Busan 48513, Korea; \\ sglee1125@pknu.ac.kr \\ * Correspondence: bohkyung.kim@pusan.ac.kr; Tel.: +82-51-510-2844 \\ + Co-first author, these authors contributed equally to this study.
}

Citation: Jeon, S.; Lee, S.; Choi, Y.; Kim, B. The Effects of PolyphenolRich Black Elderberry on Oxidative Stress and Hepatic Cholesterol Metabolism. Appl. Sci. 2021, 11, 10018. https://doi.org/10.3390/ app112110018

Academic Editor: Wojciech

Kolanowski

Received: 6 October 2021

Accepted: 25 October 2021

Published: 26 October 2021

Publisher's Note: MDPI stays neutral with regard to jurisdictional claims in published maps and institutional affiliations.

Copyright: () 2021 by the authors. Licensee MDPI, Basel, Switzerland. This article is an open access article distributed under the terms and conditions of the Creative Commons Attribution (CC BY) license (https:// creativecommons.org/licenses/by/ $4.0 /)$.

\begin{abstract}
Black elderberry (Sambucus Nigar) with high polyphenol content has been reported to have a hypolipidemic effect, but its underlying mechanisms have not been well characterized. In the present study, we investigated the effects of polyphenol-rich black elderberry (BEE) on oxidative stress and hepatic lipid metabolism. The total antioxidant activity of BEE was evaluated. The expression of genes for lipid metabolism was measured in 50 or $100 \mu \mathrm{g} / \mathrm{mL}$ of BEE-treated HepG2 cells. The mRNA and protein levels of genes for cholesterol metabolisms, i.e., sterol regulatory element-binding protein 2, 3-hydroxy-3-methylglutaryl coenzyme A reductase, and low-density lipoprotein receptor, were decreased by BEE. There was marked induction of genes for high-density lipoprotein metabolism, i.e., scavenger receptor class B type 1and ATP-binding cassette (ABC) transporter A1 in BEE-treated cells. The expression of canalicular efflux transporter for hepatic cholesterol and bile acids, such as ABCG5/G8 and ABCB11, was significantly increased by BEE treatment. There was no alteration of the lipogenic genes, whereas BEE significantly decreased the expression of genes for fatty acid oxidation. BEE significantly altered the expression of histone deacetylase and sirtuins. These data suggest that the hypocholesterolemic effects of BEE may be attributed to the alteration of genes for hepatic cholesterol synthesis and flux.
\end{abstract}

Keywords: black elderberry; antioxidant; cholesterol metabolism; HepG2 cells

\section{Introduction}

Cardiovascular disease (CVD) is one of the leading causes of death worldwide [1]. The risk factors of CVD are obesity, hypertension, hyperglycemia, chronic low-grade inflammation, oxidative stress, and dyslipidemia [2]. Dyslipidemia, including hypercholesterolemia and hypertriglyceridemia, is considered as the primary risk factor of CVD [3]. Dysregulation of cholesterol homeostasis leads to hypercholesterolemia and increases the risk of atherosclerotic CVD. Cholesterol homeostasis is maintained by the dynamic interaction between the liver and intestine. The homeostatic pathway for cholesterol metabolism includes de novo synthesis, absorption, efflux, conversion, and excretion of cholesterol [4]. Notably, the liver represents the principal organ that controls the cholesterol net balance [5]. High-density lipoprotein (HDL)-driven reverse cholesterol transport (RCT) mediated by the liver is considered the only route for cholesterol disposal in the body. In this hepatobiliary cholesterol excretion, the excess cholesterol from peripheral tissue is delivered to the liver for subsequent excretion as fecal neutral sterol or bile acids [6]. Recently, mounting evidence supports the existence of transintestinal cholesterol excretion (TICE), and hepatobiliary secretion mediated by RCT via HDL is not the only route to eliminate excess cholesterol [7-9]. This paradigm suggests that the underestimated role of the intestine in the classical concepts of cholesterol elimination requires modification and that TICE stimulation can be an effective target for the prevention of CVD [7]. However, the nonbiliary 
TICE pathway is an alternative route, and underlying molecular mechanisms remain unknown $[8,9]$. The relative contribution of the biliary and nonbiliary pathways to cholesterol excretion is not well established. However, animal and clinical studies have reported that hepatobiliary cholesterol excretion accounts for more than $70 \%$ of fecal neutral sterols in normal metabolism [10]. Therefore, most of the studies on lowering plasma cholesterol are intensively focused on hepatic cholesterol regulation. Medications-i.e., statins, PCSK9 inhibitors, selective cholesterol absorption inhibitors, resins, fibrates, and niacin-are commonly prescribed to lower plasma cholesterol and triglycerides. However, adverse effects of these drugs include diarrhea, constipation, nausea, vomiting, stomach cramps, muscle pain, dizziness, flushing, skin rashes, heartburn, ocular disorders, and abnormal liver function [11-15]. Therefore, natural products and dietary agents with hypocholesterolemic effects are of intense interest. Natural products, especially polyphenol-rich foods, were claimed to have protective effects against CVD by exerting protective effects on oxidative stress, inflammation, endothelial function, and dyslipidemia [16-22].

Black elderberry (Sambucus Nigar), native to North America and Europe, has been widely used as supplementation to relieve cold and flu symptoms and support the immune system $[23,24]$. It has a long history of use as traditional medicine for diaphoresis, antipyretics, and diuretics in European countries. Studies reported that black elderberry has protective effects on preventing metabolic disease by exerting antioxidant, antiinflammatory, antibacterial, antitumor, antiobesity, hypoglycemic, and hypolipidemic activity. Relatively high concentrations of polyphenols in black elderberry, particularly anthocyanins, are claimed as the bioactive components with antioxidant and anti-inflammatory effects [25-28]. The major anthocyanins found in the polyphenol-rich black elderberry extract, the standardized black elderberry extract used in the present study, were cyanidin 3-glucoside and cyanidin 3-sambubioside [29]. Cyanidin 3-glucoside has cardioprotective effects in animal and clinical trials by modulating oxidative stress and inflammatory biomarkers [30,31]. For cholesterol metabolism, several studies reported the effects of black elderberry in regulating cholesterol metabolism in diet-induced obesity mice and apoE knockout mice [29,32]. Moreover, we previously reported the hypocholesterolemic effects of polyphenol-rich black elderberry extract (BEE) by altering genes to stimulate TICE in Caco-2 cells [33]. However, little is known about the effect and the underlying mechanisms of BEE on regulating hepatic cholesterol metabolism. The objective of this study was to confirm the antioxidant activity of BEE and to investigate whether dietary BEE with antioxidant effects can regulate genes critical for hepatic cholesterol metabolism using HepG2 cells.

\section{Materials and Methods}

\subsection{Chemicals and Reagents}

Folin-Ciocalteu reagent, gallic acid, 2,2-diphenyl-1-picrylhydrazyl (DPPH), L-ascorbic acid, Iron(III) chloride hexahydrate, 2,4,6-Tris(2-pyridyl)-s-triazine, Iron(II) sulfate heptahydrate, and 2,2'-Azobis(2-methylpropionamidine) dihydrochloride were purchased from Sigma-Aldrich (St. Louis, MO, USA). 2,2'-Azino-bis(3-ethylbenzothiazoline-6-sulfonic acid) diammonium salt (ABTS) was purchased from Roche (Mannheim, Germany). Unless indicated, all reagents for cell culture were purchased from Hyclone (South Logan, UT, USA). Artemis International (Fort Wayne, IN, USA) kindly provided the polyphenol-rich black elderberry extract (BEE), standardized to anthocyanin content of $13 \%$, for the experiment.

\subsection{Quantification of Total Phenolic, Flavonoid, and Anthocyanin Content}

The quantification of total phenolic, flavonoid, and anthocyanin in BEE was carried out in triplicate. The total phenolic amount was measured by colorimetric assay using Folin-Ciocalteu reagent. Briefly, $10 \mu \mathrm{L}$ of BEE sample was mixed with $130 \mu \mathrm{L}$ of deionized water followed by the addition of $10 \mu \mathrm{L}$ of Folin-Ciocalteu reagent. After $6 \mathrm{~min}, 1 \mathrm{~mL}$ of $7 \% \mathrm{Na}_{2} \mathrm{Co}_{3}$ solution was added and incubated for $90 \mathrm{~min}$. The absorbance of the mixture was measured at $750 \mathrm{~nm}$ using a microplate reader. Total phenolic content in 
BEE was described as mg of gallic acid equivalents (GAE)/g dry weight. Total flavonoid amount was measured using a modified method of Zhishen et al. [34]. Briefly, $25 \mu \mathrm{L}$ of the extract was mixed with $160 \mu \mathrm{L}$ of deionized water for $5 \mathrm{~min}$. Then, $7.5 \mu \mathrm{L}$ of $5 \% \mathrm{NaNO}_{2}$ and $7.5 \mu \mathrm{L}$ of $10 \% \mathrm{AlCl}_{3}$ were added, followed by $100 \mu \mathrm{L}$ of $1 \mathrm{M} \mathrm{NaOH}$. The mixture was gently mixed by pipetting to remove haze, and the absorbance was measured at $510 \mathrm{~nm}$. Total flavonoids content was expressed as $\mathrm{mg}$ quercetin equivalents (QE)/g dry weight. Total anthocyanin content was determined by the $\mathrm{pH}$ differential method of Giusti and Wrolstad [35]. An amount of $75 \mu \mathrm{L}$ of $1 \mathrm{mg} / \mathrm{mL}$ BEE was mixed respectively with $1425 \mu \mathrm{L} 0.025 \mathrm{M}$ potassium chloride buffer ( $\mathrm{pH} 1.0)$ and $0.4 \mathrm{M}$ sodium acetate buffer ( $\mathrm{pH} 4.5$ ) and incubated at $23{ }^{\circ} \mathrm{C}$ for $15 \mathrm{~min}$. The absorbance was measured at 510 and $700 \mathrm{~nm}$. The content of total anthocyanin was expressed as $\mathrm{mg}$ cyanidin-3glucoside equivalents (CGE) / $100 \mathrm{~g}$ dried weight and calculated as follows: total monomeric anthocyanin content $(\mathrm{mg} \mathrm{CGE} / \mathrm{L})=(\mathrm{A} \times 1000 \times \mathrm{MW} \times \mathrm{DF}) / \varepsilon \times 1)[\mathrm{MW}=449.2, \varepsilon=26900]$, $\mathrm{A}=(\mathrm{A} 510-\mathrm{A} 700) \mathrm{pH} 1.0-(\mathrm{A} 510-\mathrm{A} 700) \mathrm{pH} 4.5$.

\subsection{Total Antioxidant Capacity}

The total antioxidant capacity of BEE was examined by measuring DPPH and ABTS radical scavenging activity and reducing power. All of the assays were performed in triplicate. An amount of $50 \mu \mathrm{L}$ of BEE was mixed with $2.95 \mathrm{~mL}$ of $100 \mu \mathrm{M}$ DPPH solution for $30 \mathrm{~min}$. The absorbance was measured at $510 \mathrm{~nm}$. For the reference, $50 \%$ aqueous methanol was used. The ABTS radical scavenging activity was determined by the following method. An amount of $1.0 \mathrm{mM}$ of AAPH was mixed with $2.5 \mathrm{mM}$ ABTS diammonium salt in a phosphate-buffered solution. The mixture was incubated at $70{ }^{\circ} \mathrm{C}$ for $30 \mathrm{~min}$ to generate ABTS radical solution and filtered using a PVDF filter. An amount of $5 \mu \mathrm{L}$ of BEE was added to $245 \mu \mathrm{L}$ of the resulting blue/green ABTS radical solution and incubated at $37{ }^{\circ} \mathrm{C}$ for $10 \mathrm{~min}$. The decrease in absorbance was measured at $734 \mathrm{~nm}$. For the reference, $0.1 \% \mathrm{HCl}$ aqueous solution was used. The antioxidant capacity of BEE was expressed as mg Vitamin C Equivalents Antioxidant Capacity (VCEAC)/g dry weight.

The ferric reducing antioxidant power (FRAP) of BEE was measured by a slight modification of Benzie and Strain's method [36]. The reagent was prepared by mixing 10 volumes of acetate buffer (300 mM, pH 3.6) with 1 volume of $10 \mathrm{mM}$ TPTZ (2,4,6-tri[2 -pyridyl]-s-triazine) solution, 1 volume of $20 \mathrm{mM}$ of $\mathrm{FeCl}_{3}$ solution, and 1.2 volume of distilled water and kept at $37^{\circ} \mathrm{C}$ until use. Diluted BEE mixed with $250 \mu \mathrm{L}$ of FRAP reagent was incubated for $4 \mathrm{~min}$ at $37^{\circ} \mathrm{C}$, and the absorbance was measured at $593 \mathrm{~nm}$. Ferrous sulfate $\left(\mathrm{FeSO}_{4}\right)$ was used for a standard curve $(0.1 \mathrm{mM}$ to $1.0 \mathrm{mM})$. The reducing power was expressed as $\mathrm{mM}$ FeSO4 equivalent/g dw.

\subsection{Cell Culture and Treatment}

The human liver adenocarcinoma HepG2 cells from American Type Culture Collection (Manassas, VA, USA) were cultured in Dulbecco's Modified Eagles Medium supplemented with $100 \mathrm{U} / \mathrm{mL}$ of penicillin, $100 \mu \mathrm{g} / \mathrm{mL}$ of streptomycin, $1 \times$ vitamins, and $10 \%$ fetal bovine serum in a humidified $\mathrm{CO}_{2}$ chamber at $37^{\circ} \mathrm{C}$. When the cells were $\sim 90 \%$ confluent, 50 or $100 \mu \mathrm{g} / \mathrm{mL}$ of BEE was treated for $24 \mathrm{~h}$. The concentrations of BEE were determined by cytotoxicity using Cell Count kit-8 (Dojindo Molecular Technologies, Rockville, MD, USA). There were no significant differences in the viability of HepG2 cells treated up to $100 \mu \mathrm{g} / \mathrm{mL}$ of BEE. Therefore, 50 or $100 \mu \mathrm{g} / \mathrm{mL}$ BEE was used in the experiments. HepG2 cells without BEE served as a control for all experiments.

\subsection{Quantitative Real-Time Polymerase Chain Reaction (qRT-PCR)}

Total RNA was isolated from the cells using TRIzol reagent (Invitrogen, Grand Island, NY, USA), and qRT-PCR analysis for hepatic gene expression was conducted as previously described using the SYBR Green procedure and CFX96 real-time PCR detection system (Bio-Rad, Hercules, CA, USA) [33]. Primer sequences were designed according to the 
GeneBank database using the Beacon Designer software (Premier 20 Biosoft, Palo Alto, CA, USA).

\subsection{Western Blot}

The protein levels in BEE-treated Caco-2 cells were measured by Western blot analysis, as previously described [37]. The Western blot analysis was performed twice, and the representative images are shown as results. Chemidoc XRS+ (Bio-Rad) and Image Lab software (Bio-Rad) were used for the analysis. The antibodies for ATP-binding cassette transporter A1 (ABCA1), ABCG5, ABCG8, 3-hydroxy-3-methylglutaryl coenzyme A reductase (HMGR), LDL receptor (LDLR), Niemann-Pick C1 Like 1 (NPC1L1), scavenger receptor class $B$ type 1 (SR-B1), and sterol regulatory element-binding protein 2 (SREBP-2) were purchased from Abcam (Cambridge, MA, USA). $\beta$-actin purchased from Sigma (St. Louis, MO, USA) was used as a loading control.

\subsection{Statistical Analysis}

One-way analysis of variance (ANOVA) and Newman-Keuls post hoc analysis was performed to detect significance using GraphPad Prism 7 (GraphPad Software, La Jolla, CA, USA). All values are expressed as mean \pm SEM.

\section{Results}

\subsection{Composition and Total Antioxidant Capacity of BEE}

To investigate the antioxidant effects of BEE, we first measured the content of total polyphenol, flavonoid, and anthocyanin in BEE. Total phenolics, flavonoids, and anthocyanin in BEE were $222.8 \pm 15.1 \mathrm{mg} \mathrm{GAE} / \mathrm{g}$, $522.9 \pm 43.9 \mathrm{mg} / \mathrm{QE} / \mathrm{g}$, and $242.9 \pm 7.7 \mathrm{mg}$ CGE $/ \mathrm{g}$, respectively. The total antioxidant capacity of BEE was examined by measuring DPPH, ABTS radical scavenging activity, and reducing power. BEE exerted $199.2 \pm 21.2 \mathrm{mM} \mathrm{VCE} / \mathrm{g}$ of $\mathrm{DPPH}$ and $369.1 \pm 30.6 \mathrm{mM} \mathrm{VCE} / \mathrm{g}$ of ABTS radical scavenging activity, and the reducing power exerted $3.0 \pm 0.3 \mathrm{mM} \mathrm{FeSO}_{4} / \mathrm{g}$ of FRAP (Table 1).

Table 1. Composition and total antioxidant capacity of BEE.

\begin{tabular}{|c|c|c|c|c|c|c|}
\hline & \multirow{2}{*}{$\begin{array}{c}\text { Total } \\
\text { Phenolics } \\
\text { (mg GAE/g) }\end{array}$} & \multirow{2}{*}{$\begin{array}{c}\text { Total } \\
\text { Flavonoid } \\
\text { (mg QE/g) }\end{array}$} & \multirow{2}{*}{$\begin{array}{c}\text { Total } \\
\text { Anthocyanin } \\
\text { (mg CGE/g) }\end{array}$} & \multicolumn{3}{|c|}{ Total Antioxidant Capacity } \\
\hline & & & & $\begin{array}{c}\text { DPPH } \\
\text { (mM VCE/g) }\end{array}$ & $\begin{array}{c}\text { ABTS } \\
\text { (mM VCE/g) }\end{array}$ & $\begin{array}{c}\text { FRAP } \\
\left(\mathrm{mM} \mathrm{FeSO}_{4} / \mathrm{g}\right)\end{array}$ \\
\hline BEE & $222.8 \pm 15.1$ & $522.9 \pm 43.9$ & $242.9 \pm 7.7$ & $199.2 \pm 21.2$ & $369.1 \pm 30.6$ & $3.0 \pm 0.3$ \\
\hline
\end{tabular}

Data represent mean \pm SEM. DPPH radical scavenging activity, ABTS radical scavenging activity, and FRAP were measured for the total antioxidant capacity analysis. GAE, gallic acid equivalents; QE, quercetin equivalents; CGE, cyanidin-3-glucoside equivalents; VCE, vitamin C equivalents.

\subsection{Effects of BEE on the Genes Involved in Cholesterol Biosynthesis and Absorption}

The mRNA abundance of genes involved in de novo synthesis and flux of cholesterol was measured to investigate the effects of BEE on hepatic cholesterol metabolism. SREBP2, the critical transcription factor for cholesterol metabolism, modulates the expression of HMGR and LDLR. HMGR is the rate-limiting enzyme controlling cholesterol biosynthesis, and LDLR is the receptor responsible for LDL-derived cholesterol uptake. BEE significantly $(p<0.05)$ and dose-dependently decreased the expression of SREBP2, with a concomitant decrease in the expression of HMGR and LDLR. The expression of LDLR-related protein 1 (LRP1), a member of the LDLR family, was not altered by BEE treatment. Hepatic SR-B1, the receptor for HDL uptake, plays a crucial role in mediating reverse cholesterol transport (RCT). ABCA1, the transport for cholesterol efflux, is involved in the biogenesis of HDL and promotes RCT. In BEE-treated HepG2 cells, there was a significant $(p<0.05)$ induction of the expression of SR-B1 and ABCA1 compared with control (Figure 1). Furthermore, the protein levels of cholesterol metabolism altered by $\mathrm{BE}$ exerted consistent results with mRNA results. The protein abundance of SREBP2, HMGR, and LDLR was noticeably 
decreased, whereas the SR-B1 and ABCA1 proteins were markedly increased in the BEEtreated HepG2 cells (Figure 2).

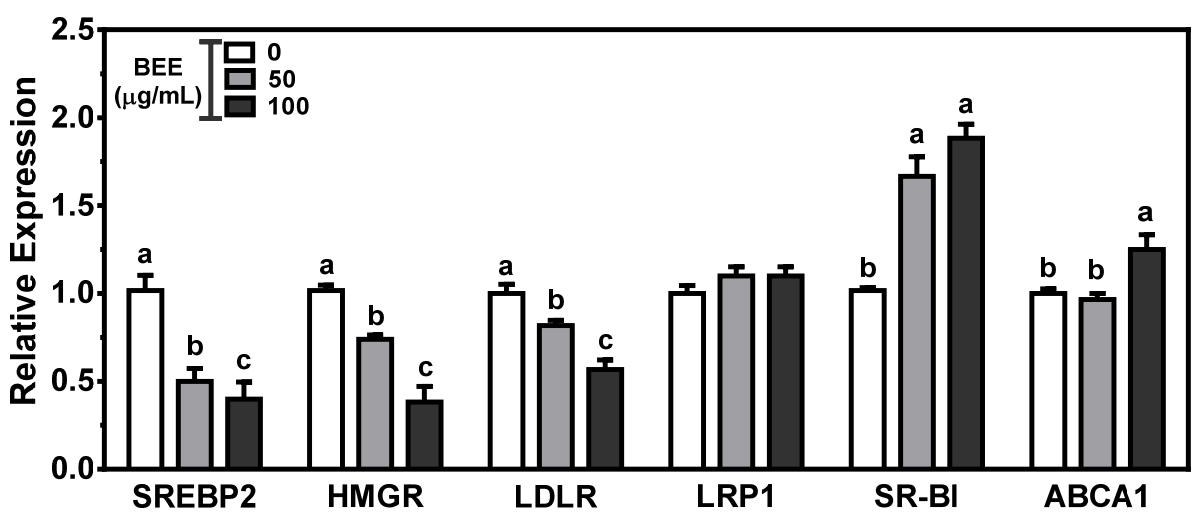

Figure 1. Expression of genes for cholesterol biosynthesis and absorption in BEE-treated HepG2 cells. Cells were treated with 50 or $100 \mu \mathrm{g} / \mathrm{mL}$ of BEE for $24 \mathrm{~h}$. The gene expression was measured by qRT-PCR analysis. Data are expressed as relative expressions to control. Different letters indicate significant differences $(p<0.05)$. Values are means \pm S.E.M. $\mathrm{n}=6$.

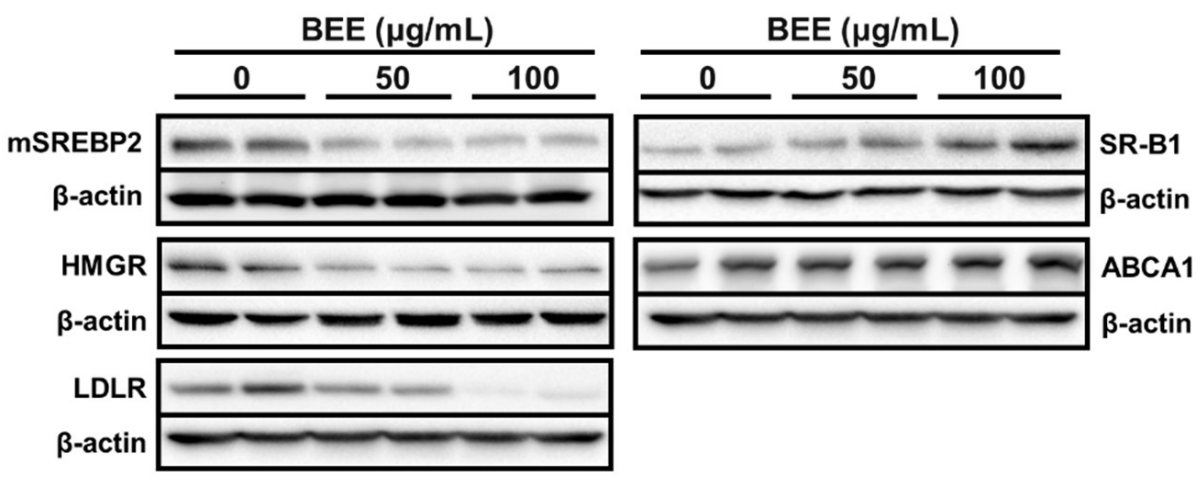

Figure 2. The proteins for cholesterol biosynthesis and absorption in BEE-treated HepG2 cells. The cells were treated with 50 or $100 \mu \mathrm{g} / \mathrm{mL}$ of BEE for $24 \mathrm{~h}$. The representative image of the Western blot from two different experiments is shown. $\beta$-actin was used as a loading control.

\subsection{Effects of BEE on the Genes Involved in Biliary Cholesterol Efflux}

Next, we measured the genes responsible for the cholesterol efflux in HepG2 cells. Hepatic NPC1L1 reabsorbs the cholesterol from bile to the liver, whereas ABCG5/G8 plays an essential role in hepatobiliary cholesterol secretion. The expression of NPC1L1 was dose-dependently and significantly $(p<0.05)$ decreased by BEE. Furthermore, significant induction $(p<0.05)$ of ABCG5/G8 was observed in BEE-treated HepG2 cells. For the genes involved in bile acid secretion, the mRNA levels of CYP7A1 and ABCB11 were significantly $(p<0.05)$ increased by BEE treatment. The protein level of NPC1L1 was noticeably reduced in BEE-treated HepG2 cells. Moreover, the protein levels of transporters for biliary cholesterol secretion, i.e., ABCG5 and ABCG8, were noticeably increased in BEE-treated HepG2 cells (Figure 3). 


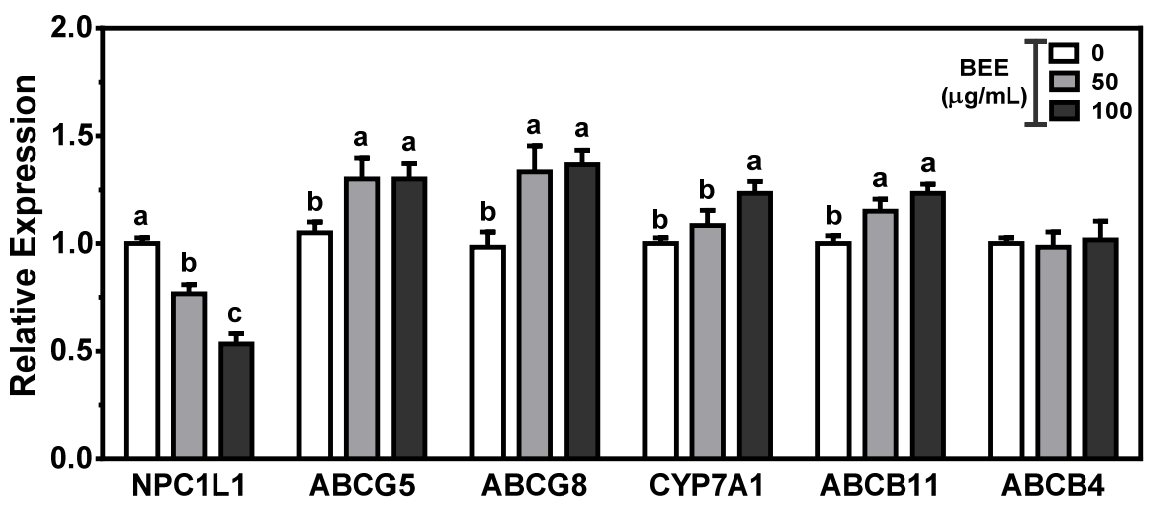

(a)

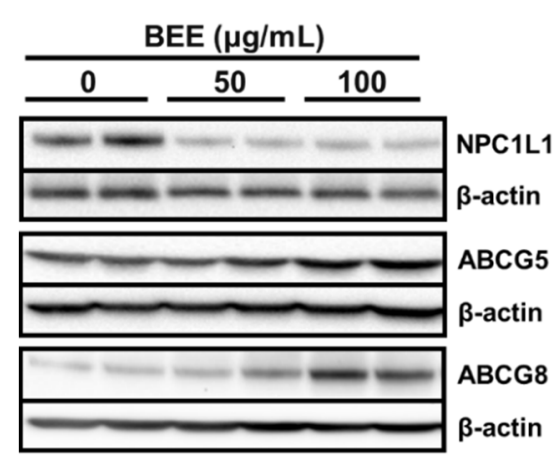

(b)

Figure 3. The effect of BEE on the genes for cholesterol flux in HepG2 cells. The cells were treated with $50 \mathrm{or} 100 \mu \mathrm{g} / \mathrm{mL}$ of BEE for $24 \mathrm{~h}$. (a) The hepatic gene expression was measured by qRT-PCR analysis. Data are expressed as relative expressions to control. Different letters indicate significant differences $(p<0.05)$. Values are means \pm S.E.M. $n=6$. $(\mathbf{b})$ The representative image of the Western blot from two different experiments is shown. $\beta$-actin was used as a loading control.

\subsection{Effects of BEE on the Genes Involved in Fatty Acid Metabolism}

The mRNA expression of genes involved in the fatty acid synthesis and $\beta$-oxidation were measured in BEE-treated HepG2 cells. SREBP1c, the transcription factor for fatty acid synthesis, can activate lipogenic genes such as FAS and SCD-1. Fatty acid oxidation is mediated by essential enzymes such as mitochondrial CPT1 and peroxisomal ACOX. The expression of genes for de novo lipogenesis was not altered by BEE treatment. In contrast, there were significant reductions $(p<0.05)$ in genes for fatty acid oxidation, i.e., CPT1 and ACOX, in BEE-treated cells (Figure 4).

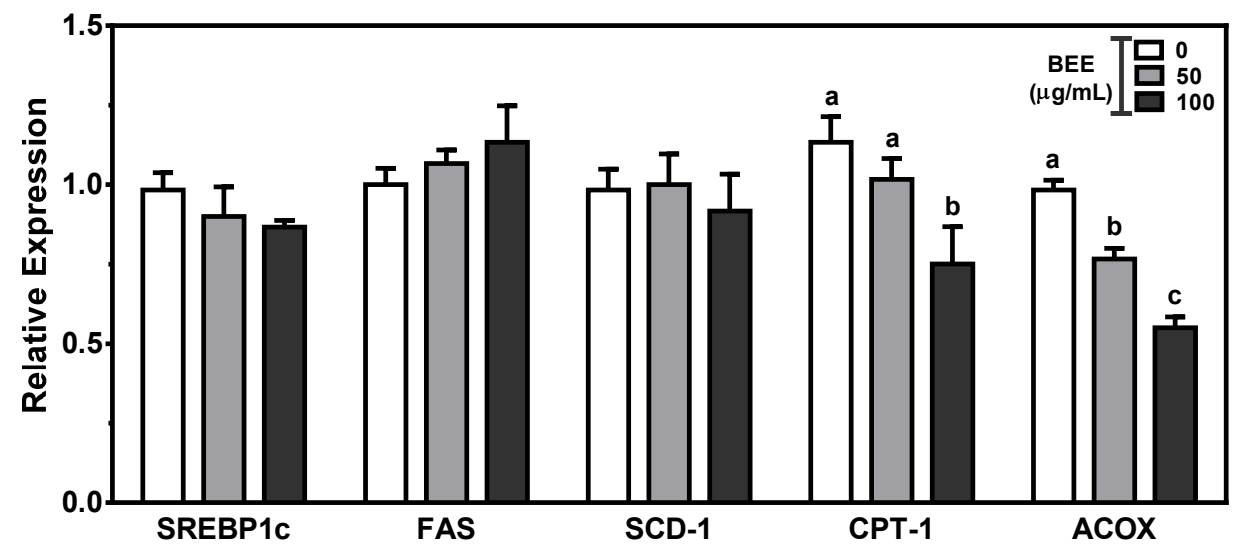

Figure 4. The expression of genes for fatty acid metabolism in BEE-treated HepG2 cells. Cells were treated with 50 or $100 \mu \mathrm{g} / \mathrm{mL}$ of BEE for $24 \mathrm{~h}$. The mRNA abundance was measured by qRT-PCR analysis. Data are expressed as relative expressions to control. Different letters indicate significant differences $(p<0.05)$. Values are means \pm S.E.M. $\mathrm{n}=6$.

\subsection{Effects of BEE on the Alteration of HDACs and SIRTs}

The expression of histone deacetylases (HDACs) and sirtuins (SIRTs) was measured to examine the potent effects of BEE on the modulation of HDACs and SIRTs. There were significant reductions $(p<0.05)$ in the expression of HDAC4, HDAC6, HDAC9, and HDAC11 in $100 \mu \mathrm{g} / \mathrm{mL}$ of BEE-treated HepG2 cells. There was no alteration of HDAC1, HDAC2, HDAC3, HDAC5, HDAC7, HDAC8, and HDAC10 by BEE treatment (Figure 5). Furthermore, the expression of SIRT1, SIRT2, and SIRT3 was decreased by BEE treatment. BEE did not alter the expression of SIRT4 to SIRT 7 in HepG2 cells (Figure 6). 


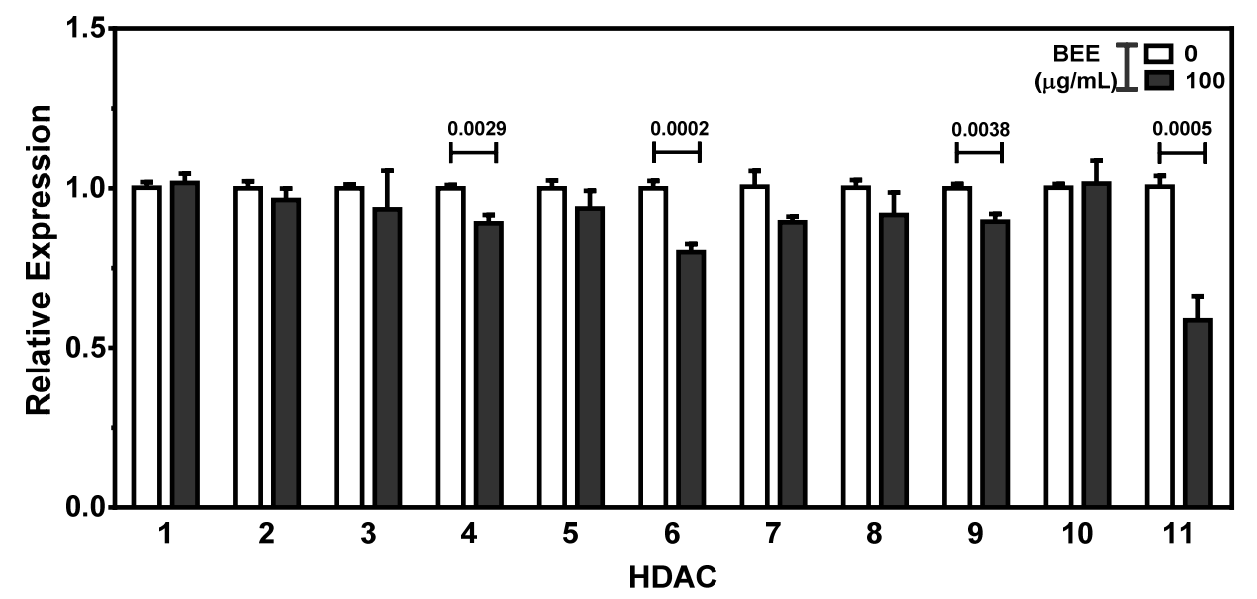

Figure 5. The effects of BEE on the regulation of HDACs in HepG2 cells. The cells were treated with $100 \mu \mathrm{g} / \mathrm{mL}$ of BEE for $24 \mathrm{~h}$. The expression of HDAC isoforms was measured by qRT-PCR. Data are expressed as relative expressions of control. Different letters indicate significant differences $(p<0.05)$. Values are means \pm S.E.M. $\mathrm{n}=6$.

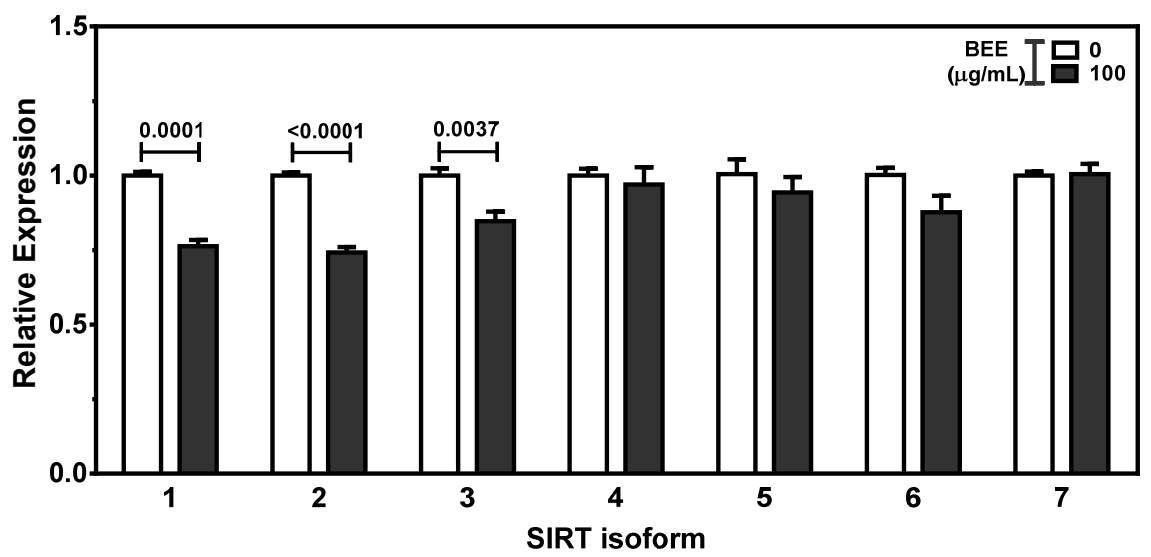

Figure 6. The effects of BEE on the alteration of SIRTs in HepG2 cells. The cells were treated with $100 \mu \mathrm{g} / \mathrm{mL}$ of BEE for $24 \mathrm{~h}$. The expression of SIRT isoforms was measured by qRT-PCR. Data are expressed as relative expressions of control. Different letters indicate significant differences $(p<0.05)$. Values are means \pm S.E.M. $\mathrm{n}=6$.

\section{Discussion}

CVD and its associated metabolic diseases are the primary health problem worldwide, and one effective strategy for the prevention of CVD is targeting hypolipidemia [3]. Herbal medicines and natural compounds with antioxidant and anti-inflammatory properties are claimed to be effective for preventing these diseases [38,39]. Cellular cholesterol regulation is associated with plasma cholesterol levels and is essential to avoiding hypercholesterolemia and hypertriglyceridemia [40]. Black elderberry and its bioactive components, polyphenols and anthocyanins, are well known for their potent effects on oxidative stress and inflammation $[23-28,41]$. However, little is known about whether black elderberry has effects on hepatic cholesterol metabolism. In the present study, the protective effects of BEE on oxidative stress and hepatic cholesterol metabolism were investigated using an in vitro assay and HepG2 cells.

Consistent with previous studies about the antioxidant effect of black elderberry, we confirmed the antioxidant effects of BEE by DPPH and ABTS radical scavenging effect and reducing power [25,26].

SREBPs are the master regulator of lipid homeostasis [42]. SREBP2 regulates genes for cholesterol metabolism, whereas SREBP1c regulates the lipogenic genes [42]. SREBP-2, 
the transcription factor for cholesterol metabolism, can modulate the expression of genes for cholesterol biosynthesis and uptake, i.e., HMGR and LDLR, in response to cellular cholesterol levels [43]. SREBP2 is regulated by two essential membrane proteins: SREBPcleavage activating protein (SCAP) and an insulin-induced gene(INSIG). The inactive SREBP2 precursor is present in the endoplasmic reticulum, with association with SCAP and INSIG. When cellular cholesterol is deprived, SCAP undergoes conformational changes and dissociates from INSIG, and it facilitates the transport of SREBP2 to the Golgi apparatus as the initial step in SREBP2 activation. SREBP2 proteins are cut by Golgi-specific S1P and S2P proteases, producing a mature transcriptionally active SREBP fragment that is subsequently translocated to the sterol regulatory element of the nucleus [43,44]. With the response of cellular cholesterol levels, SREBP2 can induce HMGR and LDLR. Statins are a commonly prescribed medication for CVD prevention, and they inhibit HMGR, the rate-controlling enzyme for de novo synthesis of cholesterol. Hepatic LDLR and LRP1 play a prominent role in the clearance of cholesterol-abundant apoE containing lipoproteins [45]. In the present study, there was a significant reduction in the genes involved in cholesterol biosynthesis and uptake. BEE inhibited SREBP2 maturation, followed by decreases in HMGR and LDLR abundance. Consistent with our results, luteolin and barley sprout extract containing polyphenols significantly downregulated SREBP2 and HMGR expression [46,47]. In highfat diet-induced hyperlipidemia mice, raspberry extract rich in anthocyanins modulated cholesterol metabolism by inhibiting HMGR and LDLR [48]. These results support the finding that polyphenols in BEE may be responsible for the downregulation of SREBP2 with concomitant reductions in HMGR and LDLR in the liver. SR-B1, a unique ligand membrane receptor, selectively uptakes HDL-associated cholesterol for the clearance in circulation and concomitant modulation of RCT [49,50]. Overexpression of hepatic SR-B1 in the mouse decreased plasma HDL and increased biliary cholesterol concentration in the liver and gallbladder [51]. ABCA1, the transporter for hepatic cholesterol efflux, is required for nascent HDL biogenesis [52,53]. There was a significant induction of SR-B1 and ABCA1 in BEE-treated HepG2 cells. Consistent with these results, polyphenol-abundant natural products induced hepatic SR-B1 and ABCA1 that are involved in HDL cholesterol metabolism. Quercetin, a polyphenolic flavonoid, significantly increased the expression of SR-B1 in HepG2 cells and in the liver of C57BL/6J mice [54]. Propolis and red wine concentrate increased hepatic ABCA1 expression in the mice and HepG2 cells $[55,56]$. These observations support the possibility that the hypocholesterolemic effects of BEE may be attributed to altering genes for cholesterol biosynthesis and uptake in the liver.

The function of NPC1L1 is cholesterol absorption in the small intestine and liver [57]. Inhibitor of NPC1L1, ezetimibe, has been clinically used as an effective cholesterol-lowering medication $[58,59]$. Hepatic NPC1L1 transports newly secreted biliary cholesterol back into hepatocytes to avoid excessive loss of cellular cholesterol [57,60]. In contrast, ABCG5/G8 in the hepatocyte transports unmetabolized free cholesterol of the liver into bile for direct secretion $[60,61]$. The expression of mRNA and protein of NPC1L1 was decreased, whereas ABCG5/G8 level was increased in BEE-treated HepG2 cells. Consistent with our findings, the expression of NPC1L1 was significantly decreased by Opuntia ficus indica high in phenolic compounds in HepG2 cells [62]. Coffea arabica pulp containing polyphenols alleviated hepatic lipid content by increasing cholesterol efflux transporter ABCG5/G8 in HepG2 cells [63]. CYP7A1 is the critical enzyme for the conversion of cholesterol to bile acids in the liver [64]. ABCB11, a bile salt export pump (BSEP), is present in the canalicular membrane of hepatocytes and mediates biliary secretion [65-67]. BEE altered the genes for bile acid synthesis and secretion in HepG2 cells. Consistent with our results, dietary resveratrol increased the mRNA and protein levels of hepatic CYP7A1, with a concomitant increase in CYP7A1 enzyme activity in high-fat-fed mice [37]. Polyphenols as a dietary antioxidant are reported to regulate cholesterol metabolism via bile acid biosynthesis [68]. Furthermore, cyanidin 3-glucoside, the major anthocyanin present in BEE with antioxidant properties, exerted hypocholesterolemic activity by activating hepatic CYP7A1 for bile acid excretion [69]. In the present study, BEE significantly altered the genes involved in 
cholesterol transport in the direction of biliary cholesterol excretion. These results indicate that BEE can exert hypocholesterolemic effects by facilitating the cholesterol from the liver into bile for secretion.

Fatty acid metabolism is tightly associated with dyslipidemia. The genes for fatty acid synthesis and oxidation were measured in BEE-treated HepG2 cells. SREBP1c preferentially activates the transcription of genes required for fatty acid and triglyceride synthesis, such as ACC, FAS, and SCD-1 $[42,44]$. CPT1 is a mitochondrial enzyme required for the fatty acid $\beta$-oxidation process [70]. ACOX, the rate-limiting step of peroxisomal $\beta$-oxidation, catalyzes the very-long-chain saturated fatty acids (VLCFA). Accumulation of VLCFA in ACOX1 knockout mice confirmed the requirement for ACOX-1 for $\beta$-oxidation of these VLCFA [71-73]. In the present study, BEE altered the genes involved in fatty acid $\beta$ oxidation but not those involved in lipogenesis. Polyphenols from grape seed extract markedly increased CPT1 in HepG2 cells and human peripheral blood mononuclear cells [74].

Significant alteration of hepatic genes for cholesterol metabolism-i.e., biosynthesis, absorption, uptake, and biliary secretion-led to the investigation of the expression of HDACs and SIRTs. Several studies reported that the genes for cholesterol metabolismi.e., NPC1L1, LDLR, HMGR, CYP7A1, etc.-are under epigenetic regulation [75-77]. In the present study, BEE decreased the mRNA abundance of HDAC4, HDAC6, HDAC9, HDAC11, SIRT1, SIRT2, and SIRT3 in HepG2 cells. The alteration of SIRTs by BEE in HepG2 exerted different results from the previous study using Caco-2 cells [33]. Further study is underway to understand the effects and underlying mechanisms of BEE on the alteration of HDACs and SIRTs in both cell lines.

\section{Conclusions}

In conclusion, the expression of genes for hepatic cholesterol biosynthesis (HMGR, SREBP2) and uptake (LDLR and SR-B1) and efflux of cholesterol and bile acids (NPC1L1, ABCG5/G8, CYP7A1, and ABCB11) were altered in BEE-treated HepG2 cells. All of the gene changes modulated by BEE were in the direction of biliary cholesterol secretion. Further study is warranted to investigate which components present in BEE are attributed to the hypocholesterolemic effects of BEE by alteration of hepatobiliary cholesterol excretion. Furthermore, a comparison of various black elderberry extracts using different extract methods on oxidative stress and cholesterol metabolism is also needed. These findings suggest that black elderberry may have a hypocholesterolemic effect, in part, by altering the expression of genes involved in cholesterol metabolism in the direction of the biliary cholesterol excretion pathway. The present study supports the possibility that the consumption of black elderberry may be beneficial for the prevention of CVD.

Author Contributions: Conceptualization, B.K.; methodology, S.J., S.L., Y.C. and B.K.; validation, S.J., S.L. and B.K.; formal analysis, S.J., S.L., Y.C. and B.K.; investigation, S.J., S.L., Y.C. and B.K.; resources, S.L. and B.K.; data curation, S.J., S.L., Y.C. and B.K.; writing-original draft preparation, S.J., S.L. and B.K.; writing-review and editing, B.K.; supervision, B.K.; funding acquisition, B.K. All authors have read and agreed to the published version of the manuscript.

Funding: This work was supported by Pusan National University Research Grant, 2018.

Institutional Review Board Statement: Not applicable.

Informed Consent Statement: Not applicable.

Data Availability Statement: The data presented in this study are available in the article.

Conflicts of Interest: The authors declare no conflict of interest.

\section{References}

1. Virani, S.S.; Alonso, A.; Aparicio, H.J.; Benjamin, E.J.; Bittencourt, M.S.; Callaway, C.W.; Carson, A.P.; Chamberlain, A.M.; Cheng, S.; Delling, F.N.; et al. Heart Disease and Stroke Statistics-2021 Update: A Report From the American Heart Association. Circulation 2021, 143, e254-e743. [CrossRef] 
2. Mommersteeg, P.M.; Denollet, J.; Spertus, J.A.; Pedersen, S.S. Health status as a risk factor in cardiovascular disease: A systematic review of current evidence. Am. Hear. J. 2009, 157, 208-218. [CrossRef]

3. Nelson, R.H. Hyperlipidemia as a Risk Factor for Cardiovascular Disease. Prim. Care Clin. Off. Pr. 2013, 40, 195-211. [CrossRef]

4. Luo, J.; Yang, H.; Song, B.-L. Mechanisms and regulation of cholesterol homeostasis. Nat. Rev. Mol. Cell Biol. 2020, 21, 225-245. [CrossRef]

5. Groen, A.K.; Bloks, V.W.; Verkade, H.J.; Kuipers, F. Cross-talk between liver and intestine in control of cholesterol and energy homeostasis. Mol. Asp. Med. 2014, 37, 77-88. [CrossRef] [PubMed]

6. Millar, J.S.; Cuchel, M. Cholesterol metabolism in humans: A review of methods and comparison of results. Curr. Opin. Lipidol. 2018, 29, 1-9. [CrossRef]

7. Wang, D.Q.H.; Portincasa, P.; Tso, P. Transintestinal cholesterol excretion: A secondary, nonbiliary pathway contributing to reverse cholesterol transport. Hepatology 2017, 66, 1337-1340. [CrossRef] [PubMed]

8. Temel, R.-E.; Brown, J.-M. A new framework for reverse cholesterol transport: Non-biliary contributions to reverse cholesterol transport. World J. Gastroenterol. 2010, 16, 5946-5952. [CrossRef]

9. Temel, R.E.; Brown, J.M. A new model of reverse cholesterol transport: enTICEing strategies to stimulate intestinal cholesterol excretion. Trends Pharmacol. Sci. 2015, 36, 440-451. [CrossRef] [PubMed]

10. Grefhorst, A.; Verkade, H.J.; Groen, A.K. The TICE Pathway: Mechanisms and Lipid-Lowering Therapies. Methodist DeBakey Cardiovasc. J. 2019, 15, 70-76. [CrossRef]

11. Mizranita, V.; Pratisto, E.H. Statin-associated ocular disorders: The FDA and ADRAC data. Int. J. Clin. Pharm. 2015, 37, 844-850. [CrossRef]

12. Simonson, W. Update on statin drugs for lipid disorders. Geriatr. Nurs. 2018, 39, 350-351. [CrossRef]

13. Ábel, T.; Fehér, J. Statin treatment and muscle disorders. Orvosi Hetil. 2009, 150, 261-263. [CrossRef] [PubMed]

14. Salvatore, T.; Morganti, R.; Marchioli, R.; De Caterina, R. Cholesterol Lowering and Stroke: No Longer Room for Pleiotropic Effects of Statins-Confirmation from PCSK9 Inhibitor Studies. Am. J. Med. 2020, 133, 95-99.e6. [CrossRef]

15. Sgro, C.; Escousse, A. Side effects of fibrates (except liver and muscle). Therapie 1991, 46, 351-354.

16. Mendonça, R.D.; Carvalho, N.C.; Martin-Moreno, J.M.; Pimenta, A.M.; Lopes, A.C.S.; Gea, A.; Martinez-Gonzalez, M.; BesRastrollo, M. Total polyphenol intake, polyphenol subtypes and incidence of cardiovascular disease: The SUN cohort study. Nutr. Metab. Cardiovasc. Dis. 2019, 29, 69-78. [CrossRef] [PubMed]

17. Rienks, J.; Barbaresko, J.; Nöthlings, U. Association of Polyphenol Biomarkers with Cardiovascular Disease and Mortality Risk: A Systematic Review and Meta-Analysis of Observational Studies. Nutrients 2017, 9, 415. [CrossRef] [PubMed]

18. Quiñones, M.; Miguel, M.; Aleixandre, A. Beneficial effects of polyphenols on cardiovascular disease. Pharmacol. Res. 2013, 68, 125-131. [CrossRef]

19. Ito, F. Polyphenols can Potentially Prevent Atherosclerosis and Cardiovascular Disease by Modulating Macrophage Cholesterol Metabolism. Curr. Mol. Pharmacol. 2020, 14, 175-190. [CrossRef] [PubMed]

20. Yamagata, K. Polyphenols Regulate Endothelial Functions and Reduce the Risk of Cardiovascular Disease. Curr. Pharm. Des. 2019, 25, 2443-2458. [CrossRef]

21. Tangney, C.C.; Rasmussen, H.E. Polyphenols, Inflammation, and Cardiovascular Disease. Curr. Atheroscler. Rep. 2013, 15, 1-10. [CrossRef]

22. Quiñones, M.; Miguel, M.; Aleixandre, A. The polyphenols, naturally occurring compounds with beneficial effects on cardiovascular disease. Nutr. Hosp. 2012, 27, 76-89. [CrossRef]

23. Barak, V.; Halperin, T.; Kalickman, I. The effect of Sambucol, a black elderberry-based, natural product, on the production of human cytokines: I. Inflammatory cytokines. Eur. Cytokine Netw. 2001, 12, 290-296.

24. Młynarczyk, K.; Walkowiak-Tomczak, D.; Łysiak, G.P. Bioactive properties of Sambucus nigra L. as a functional ingredient for food and pharmaceutical industry. J. Funct. Foods 2018, 40, 377-390. [CrossRef] [PubMed]

25. Młynarczyk, K.; Walkowiak-Tomczak, D.; Staniek, H.; Kidon, M.; Łysiak, G.P. The Content of Selected Minerals, Bioactive Compounds, and the Antioxidant Properties of the Flowers and Fruit of Selected Cultivars and Wildly Growing Plants of Sambucus nigra L. Molecules 2020, 25, 876. [CrossRef]

26. Domínguez, R.; Zhang, L.; Rocchetti, G.; Lucini, L.; Pateiro, M.; Munekata, P.E.S.; Lorenzo, J.M. Elderberry (Sambucus nigra L.) as potential source of antioxidants. Characterization, optimization of extraction parameters and bioactive properties. Food Chem. 2020, 330, 127266. [CrossRef] [PubMed]

27. Zielińska-Wasielica, J.; Olejnik, A.; Kowalska, K.; Olkowicz, M.; Dembczyński, R. Elderberry (Sambucus nigra L.) Fruit Extract Alleviates Oxidative Stress, Insulin Resistance, and Inflammation in Hypertrophied 3T3-L1 Adipocytes and Activated RAW 264.7 Macrophages. Foods 2019, 8, 326. [CrossRef]

28. David, L.; Moldovan, B.; Vulcu, A.; Olenic, L.; Perde-Schrepler, M.; Fischer-Fodor, E.; Florea, A.; Crisan, M.; Chiorean, I.; Clichici, S.; et al. Green synthesis, characterization and anti-inflammatory activity of silver nanoparticles using European black elderberry fruits extract. Colloids Surf. B Biointerfaces 2014, 122, 767-777. [CrossRef] [PubMed]

29. Farrell, N.; Norris, G.; Gil Lee, S.; Chun, O.K.; Blesso, C.N. Anthocyanin-rich black elderberry extract improves markers of HDL function and reduces aortic cholesterol in hyperlipidemic mice. Food Funct. 2015, 6, 1278-1287. [CrossRef] 
30. Olivas-Aguirre, F.J.; Rodrigo-García, J.; Martínez-Ruiz, N.D.R.; Cárdenas-Robles, A.I.; Mendoza-Díaz, S.O.; Alvarez-Parrilla, E.; Gonzalez-Aguilar, G.A.; De la Rosa, L.A.; Ramos-Jimenez, A.; Wall-Medrano, A. Cyanidin-3-O-glucoside: Physical-chemistry, foodomics and health effects. Molecules 2016, 21, 1264. [CrossRef]

31. Strugała, P.; Loi, S.; Bażanów, B.; Kuropka, P.; Kucharska, A.Z.; Włoch, A.; Gabrielska, J. A Comprehensive Study on the Biological Activity of Elderberry Extract and Cyanidin 3-O-Glucoside and Their Interactions with Membranes and Human Serum Albumin Molecules 2018, 23, 2566. [CrossRef] [PubMed]

32. Farrell, N.J.; Norris, G.H.; Ryan, J.; Porter, C.M.; Jiang, C.; Blesso, C.N. Black elderberry extract attenuates inflammation and metabolic dysfunction in diet-induced obese mice. Br. J. Nutr. 2015, 114, 1123-1131. [CrossRef] [PubMed]

33. Jeon, S.; Kim, M.; Kim, B. Polyphenol-Rich Black Elderberry Extract Stimulates Transintestinal Cholesterol Excretion. Appl. Sci. 2021, 11, 2790. [CrossRef]

34. Zhishen, J.; Mengcheng, T.; Jianming, W. The determination of flavonoid contents in mulberry and their scavenging effects on superoxide radicals. Food Chem. 1999, 64, 555-559. [CrossRef]

35. Giusti, M.M.; Wrolstad, R.E. Acylated anthocyanins from edible sources and their applications in food systems. Biochem. Eng. J. 2003, 14, 217-225. [CrossRef]

36. Benzie, I.F.F.; Strain, J.J. The Ferric Reducing Ability of Plasma (FRAP) as a Measure of "Antioxidant Power": The FRAP Assay. Anal. Biochem. 1996, 239, 70-76. [CrossRef] [PubMed]

37. Chen, Q.; Wang, E.; Ma, L.; Zhai, P. Dietary resveratrol increases the expression of hepatic $7 \alpha$-hydroxylase and ameliorates hypercholesterolemia in high-fat fed C57BL/6J mice. Lipids Health Dis. 2012, 11, 56. [CrossRef]

38. Mashour, N.H.; Lin, G.I.; Frishman, W.H. Herbal Medicine for the Treatment of Cardiovascular Disease. Arch. Intern. Med. 1998 158, 2225-2234. [CrossRef]

39. Li, L.; Zhou, X.; Li, N.; Sun, M.; Lv, J.; Xu, Z. Herbal drugs against cardiovascular disease: Traditional medicine and modern development. Drug Discov. Today 2015, 20, 1074-1086. [CrossRef] [PubMed]

40. Lange, Y.; Steck, T.L. Cholesterol homeostasis and the escape tendency (activity) of plasma membrane cholesterol. Prog. Lipid Res. 2008, 47, 319-332. [CrossRef]

41. Millar, C.L.; Norris, G.H.; Jiang, C.; Kry, J.; Vitols, A.; Garcia, C.; Park, Y.; Lee, J.; Blesso, C.N. Long-Term Supplementation of Black Elderberries Promotes Hyperlipidemia, but Reduces Liver Inflammation and Improves HDL Function and Atherosclerotic Plaque Stability in Apolipoprotein E-Knockout Mice. Mol. Nutr. Food Res. 2018, 62, e1800404. [CrossRef] [PubMed]

42. Sato, R. Sterol metabolism and SREBP activation. Arch. Biochem. Biophys. 2010, 501, 177-181. [CrossRef] [PubMed]

43. Madison, B.B. Srebp2: A master regulator of sterol and fatty acid synthesis. J. Lipid Res. 2016, 57, 333-335. [CrossRef]

44. Brown, M.S.; Goldstein, J.L. Sterol regulatory element binding proteins (SREBPs): Controllers of lipid synthesis and cellular uptake. Nutr. Rev. 1998, 56, S1-S3. [CrossRef] [PubMed]

45. Van De Sluis, B.; Wijers, M.; Herz, J. News on the molecular regulation and function of hepatic low-density lipoprotein receptor and LDLR-related protein 1. Curr. Opin. Lipidol. 2017, 28, 241-247. [CrossRef]

46. Wong, T.Y.; Lin, S.-M.; Leung, L.K. The Flavone Luteolin Suppresses SREBP-2 Expression and Post-Translational Activation in Hepatic Cells. PLoS ONE 2015, 10, e0135637. [CrossRef]

47. Lee, J.H.; Lee, S.Y.; Kim, B.; Seo, W.D.; Jia, Y.; Wu, C.; Jun, H.-J.; Lee, S.-J. Barley sprout extract containing policosanols and polyphenols regulate AMPK, SREBP2 and ACAT2 activity and cholesterol and glucose metabolism in vitro and in vivo. Food Res. Int. 2015, 72, 174-183. [CrossRef]

48. Tu, L.; Sun, H.; Tang, M.; Zhao, J.; Zhang, Z.; Sun, X.; He, S. Red raspberry extract (Rubus idaeus L shrub) intake ameliorates hyperlipidemia in HFD-induced mice through PPAR signaling pathway. Food Chem. Toxicol. 2019, 133, 110796. [CrossRef] [PubMed]

49. Linton, M.F.; Tao, H.; Linton, E.F.; Yancey, P.G. SR-BI: A Multifunctional Receptor in Cholesterol Homeostasis and Atherosclerosis. Trends Endocrinol. Metab. 2017, 28, 461-472. [CrossRef]

50. Shen, W.-J.; Azhar, S.; Kraemer, F. SR-B1: A Unique Multifunctional Receptor for Cholesterol Influx and Efflux. Annu. Rev. Physiol. 2018, 80, 95-116. [CrossRef] [PubMed]

51. Kozarsky, K.F.; Donahee, M.H.; Rigotti, A.; Iqbal, S.N.; Edelman, E.R.; Krieger, M. Overexpression of the HDL receptor SR-BI alters plasma HDL and bile cholesterol levels. Nat. Cell Biol. 1997, 387, 414-417. [CrossRef]

52. Basso, F.; Freeman, L.; Knapper, C.L.; Remaley, A.; Stonik, J.; Neufeld, E.B.; Tansey, T.; Amar, M.J.A.; Fruchart-Najib, J.; Duverger, N.; et al. Role of the hepatic ABCA1 transporter in modulating intrahepatic cholesterol and plasma HDL cholesterol concentrations. J. Lipid Res. 2003, 44, 296-302. [CrossRef]

53. Field, F.J.; Watt, K.; Mathur, S.N. Origins of intestinal ABCA1-mediated HDL-cholesterol. J. Lipid Res. 2008, 49, 2605-2619. [CrossRef] [PubMed]

54. Ren, K.; Jiang, T.; Zhao, G.-J. Quercetin induces the selective uptake of HDL-cholesterol via promoting SR-BI expression and the activation of the PPAR $\gamma / \mathrm{LXR} \alpha$ pathway. Food Funct. 2018, 9, 624-635. [CrossRef] [PubMed]

55. Yü, Y.; Si, Y.; Song, G.; Luo, T.; Wang, J.; Qin, S. Ethanolic Extract of Propolis Promotes Reverse Cholesterol Transport and the Expression of ATP-Binding Cassette Transporter A1 and G1 in Mice. Lipids 2011, 46, 805-811. [CrossRef]

56. Lee, N.-H.; Choi, S.-S.; Kim, B.-B.; Kim, S.-Y.; Kang, B.-S.; Lee, S.-J.; Park, H.-J. Effect of alcohol-free red wine concentrates on cholesterol homeostasis: An in vitro and in vivo study. Process. Biochem. 2013, 48, 1964-1971. [CrossRef] 
57. Jia, L.; Betters, J.L.; Yu, L. Niemann-Pick C1-Like 1 (NPC1L1) Protein in Intestinal and Hepatic Cholesterol Transport. Annu. Rev. Physiol. 2011, 73, 239-259. [CrossRef] [PubMed]

58. Garcia-Calvo, M.; Lisnock, J.; Bull, H.G.; Hawes, B.E.; Burnett, D.; Braun, M.P.; Crona, J.H.; Davis, H.R.; Dean, D.C.; Detmers, P.A.; et al. The target of ezetimibe is Niemann-Pick C1-Like 1 (NPC1L1). Proc. Natl. Acad. Sci. USA 2005, 102, 8132-8137. [CrossRef] [PubMed]

59. Chang, T.-Y.; Chang, C. Ezetimibe Blocks Internalization of the NPC1L1/Cholesterol Complex. Cell Metab. 2008, 7, 469-471. [CrossRef]

60. Kidambi, S.; Patel, S.B. Cholesterol and non-cholesterol sterol transporters: ABCG5, ABCG8 and NPC1L1: A review. Xenobiotica 2008, 38, 1119-1139. [CrossRef]

61. Dikkers, A.; Tietge, U.-J. Biliary cholesterol secretion: More than a simple ABC. World J. Gastroenterol. 2010, 16, 5936-5945. [CrossRef] [PubMed]

62. Ressaissi, A.; Attia, N.; Pacheco, R.; Falé, P.L.; Serralheiro, M.L.M. Cholesterol transporter proteins in HepG2 cells can be modulated by phenolic compounds present in Opuntia ficus-indica aqueous solutions. J. Funct. Foods 2020, 64, 103674. [CrossRef]

63. Ontawong, A.; Pasachan, T.; Trisuwan, K.; Soodvilai, S.; Duangjai, A.; Pongchaidecha, A.; Amornlerdpison, D.; Srimaroeng, C. Coffea arabica pulp aqueous extract attenuates oxidative stress and hepatic lipid accumulation in HepG2 cells. J. Herb. Med. 2021, 29, 100465. [CrossRef]

64. Chiang, J.Y. Regulation of bile acid synthesis: Pathways, nuclear receptors, and mechanisms. J. Hepatol. 2004, 40, 539-551. [CrossRef] [PubMed]

65. Qu, X.; Zhang, Y.; Zhang, S.; Zhai, J.; Gao, H.; Tao, L.; Song, Y. Dysregulation of BSEP and MRP2 May Play an Important Role in Isoniazid-Induced Liver Injury via the SIRT1/FXR Pathway in Rats and HepG2 Cells. Biol. Pharm. Bull. 2018, 41, 1211-1218. [CrossRef]

66. Wu, G.; Wen, M.; Sun, L.; Li, H.; Liu, Y.; Li, R.; Wu, F.; Yang, R.; Lin, Y. Mechanistic insights into geniposide regulation of bile salt export pump (BSEP) expression. RSC Adv. 2018, 8, 37117-37128. [CrossRef]

67. Hayashi, H. Bile Salt Export Pump (BSEP/ABCB11): Trafficking and Sorting Disturbances. Curr. Mol. Pharmacol. 2013, 6, 95-103. [CrossRef]

68. Chambers, K.F.; Day, P.E.; Aboufarrag, H.T.; Kroon, P.A. Polyphenol Effects on Cholesterol Metabolism via Bile Acid Biosynthesis, CYP7A1: A Review. Nutrients 2019, 11, 2588. [CrossRef]

69. Wang, D.; Xia, M.; Gao, S.; Li, D.; Zhang, Y.; Jin, T.; Ling, W. Cyanidin-3-O- $\beta$-glucoside upregulates hepatic cholesterol $7 \alpha$-hydroxylase expression and reduces hypercholesterolemia in mice. Mol. Nutr. Food Res. 2012, 56, 610-621. [CrossRef]

70. Hoppel, C. The role of carnitine in normal and altered fatty acid metabolism. Am. J. Kidney Dis. 2003, 41, S4-S12. [CrossRef]

71. Christensen, E.; Woldseth, B.; Hagve, T.-A.; Poll-The, B.T.; Wanders, R.J.A.; Sprecher, H.; Stokke, O.; Christophersen, B.O. Peroxisomal $\beta$-oxidation of Polyunsaturated Long Chain Fatty Acids in Human Fibroblasts. The Polyunsaturated and the Saturated Long Chain Fatty Acids are Retroconverted by the Same Acyl-CoA Oxidase. Scand. J. Clin. Lab. Investig. 1993, 53, 61-74. [CrossRef]

72. Infante, J.P.; Tschanz, C.L.; Shaw, N.; Michaud, A.L.; Lawrence, P.; Brenna, J. Straight-Chain Acyl-CoA Oxidase Knockout Mouse Accumulates Extremely Long Chain Fatty Acids from $\alpha$-Linolenic Acid: Evidence for Runaway Carousel-Type Enzyme Kinetics in Peroxisomal $\beta$-Oxidation Diseases. Mol. Genet. Metab. 2002, 75, 108-119. [CrossRef] [PubMed]

73. Reiser, K.; Davis, M.A.; Hynes, M.J. AoxA is a major peroxisomal long chain fatty acyl-CoA oxidase required for $\beta$-oxidation in A. nidulans. Curr. Genet. 2010, 56, 139-150. [CrossRef] [PubMed]

74. Radler, U.; Stangl, H.; Lechner, S.; Lienbacher, G.; Krepp, R.; Zeller, E.; Brachinger, M.; Eller-Berndl, D.; Fischer, A.; Anzur, C.; et al. A Combination of ( $\omega-3)$ Polyunsaturated Fatty Acids, Polyphenols and L-Carnitine Reduces the Plasma Lipid Levels and Increases the Expression of Genes Involved in Fatty Acid Oxidation in Human Peripheral Blood Mononuclear Cells and HepG2 Cells. Ann. Nutr. Metab. 2011, 58, 133-140. [CrossRef]

75. Meaney, S. Epigenetic regulation of cholesterol homeostasis. Front. Genet. 2014, 5, 311. [CrossRef]

76. Kumar, A.; Kumar, S.; Vikram, A.; Hoffman, T.A.; Naqvi, A.; Lewarchik, C.M.; Kim, Y.-R.; Irani, K. Histone and DNA MethylationMediated Epigenetic Downregulation of Endothelial Kruppel-Like Factor 2 by Low-Density Lipoprotein Cholesterol. Arter. Thromb. Vasc. Biol. 2013, 33, 1936-1942. [CrossRef]

77. Malhotra, P.; Soni, V.; Kumar, A.; Anbazhagan, A.N.; Dudeja, A.; Saksena, S.; Gill, R.K.; Dudeja, P.K.; Alrefai, W.A. Epigenetic Modulation of Intestinal Cholesterol Transporter Niemann-Pick C1-like 1 (NPC1L1) Gene Expression by DNA Methylation. J. Biol. Chem. 2014, 289, 23132-23140. [CrossRef] [PubMed] 